\title{
SEX CHROMATIN FREQUENCY IN BUCCAL MUCOSA CELLS AMONG BENGALEE HINDU FEMALES OF WEST BENGAL, INDIA
}

\author{
Koel Mukherjee ${ }^{1}$, Kaustav Das ${ }^{2}$ \\ ${ }^{1}$ Anthropological Survey of India, Andaman \& Nicobar Regional Centre, Port Blair, India \\ ${ }^{2}$ Department of Anthropology, Bangabasi College, Kolkata, India \\ Rad je primljen 11.02.2021. Rad je recenziran 17.03.2021. Rad je prihvaćen 01.04.2021.
}

\begin{abstract}
INTRODUCTION: Quantitative determination of sex chromatin in cell nuclei has been demonstrated an association between the prevalence of sex chromatin and hormonal levels of female reproductive cycles.

OBJECTIVE: The objective of the present study was to understand the prevalence of sex chromatin among different hormone dependent reproductive stages of Bengalee Hindu caste females living in West Bengal, India.

SUBJECTS AND METHODS: Buccal smear samples were collected from 500 apparently healthy female participants categorized into 5 different reproductive stages of pre-menarche, menarche, pregnancy, lactation, and menopause. 100 cells from each individual and 100 participants from each group have been studied at random.

RESULTS: The result revealed a differential prevalence of sex chromatin among the participants at different reproductive stages (ranges $\leq 10->60$ ). The mean prevalence of sex chromatin was highest among lactating mothers $(59.22 \pm 4.06)$ and

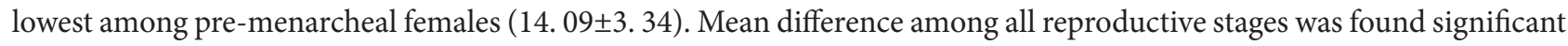
$(\mathrm{p}<0.05)$.

CONCLUSION: These results indicated a possible association between the presence of steroid hormones and the prevalence of sex chromatin. The present study also proposed sex chromatin incidence as a biomarker as well as a cytological marker of distinctive hormone-influenced reproductive phases of females.

Keywords: Sex chromatin; Bengalee Hindu Caste females; Steroid hormones; Reproductive stages

Author for correspondence: Koel Mukherjee, $\mathrm{PhD}$. Anthropologist

Physical Anthropology Division, Anthropological Survey of India, Andaman \& NicobarRegional Centre, Port Blair-744

101

Email: koelanthro@gmail.com
\end{abstract}




\section{INTRODUCTION}

Sex chromatin, the single inactive $\mathrm{X}$ chromosome, is a unique allocyclicheterochromatin structure formed in the nucleus of the mammalian female as a means of sex chromosome dosage compensation (1-3). This X chromosome inactivation in females is meant to equalize the Dosage of $\mathrm{X}$-linked genes between two sexes, coined as Dosage Compensation (4). The event of X chromosome inactivation in females is a hallmark of epigenetic gene regulation, which necessitates an entire chromosome's silencing through a wide range of mechanisms involving non-coding RNAs, chromatin modifications, and DNA- methylation (5-6). The sex chromatin consists of a loop-shaped X chromosome, usually lies along the edge of the interphase nucleus in a tightly condensed state and appears as a planoconvex mass against the inner surface of the nuclear membrane (1).

The observation of sex chromatin was applied as a useful histological method for the most reliable sex determination in humans over some decades. The sex chromatin test has been widely applied not only for the rapid identification of individuals but also used for anomalies of sexual vis-a-vis reproductive system development. The maiden attempt of Moore et al. on hermaphroditism expanded the horizon of research on the influential role of sex chromatin in gonadal dysgenesis like Turner's syndrome, Klinefelter's syndrome, hypogonadal mental patients, etc (7-10). Apart from gonadal dysgenesis, cases of primary amenorrhea also demonstrated the imperative pervasiveness of sex chromatin differentials (11-13).

Apart from sex determination and chromosomal aberrations, several studies have also demonstrated the quantitative determination of sex chromatin in cell nuclei among normal female individuals in terms of differential incidences of the sex chromatin among different ages of women (14-18). Interestingly, variations in the prevalence of sex chromatin were reported in other cells and tissues, such as vaginal smear, hair roots, and buccal smear be indicative of hormone differential in target cells (19). Attempts were also made to find out the factors influencing the frequencies of sex chromatin. Effect of hormonal factors on the frequency of sex chromatin had been subjected to some studies in non-Indian samples (20-21). However, studies on the Indian context found to be scanty but indicative of a possible association between the alternation in sex hormone levels and frequency of sex chromatinand in corroboration with non-Indian samples (14, 17-18). In view of the above, the present studyhas attempted to evaluate the prevalence of sex chromatin in different reproductive stages among the Bengalee Hindu Caste females of West Bengal, India.

\section{MATERIALS AND METHODS}

A total number of 500 apparently healthy females of different reproductive stages from different castes of the Bengalee Hindu population have been selected from Kolkata metropolitan city of West Bengal, India. All the participants were categorized into 5 different reproductive stages: pre-menarche, menarche, pregnancy, lactation, and menopause. The distribution of the sample population in each group along with their selection criteria is mentioned in table 1. After obtaining written consent from the participants, the buccal smear sample collection and laboratory procedure has been performed by following standard technique (22-23). 100 cells from each individual have been studied at random and scanned under $(10 \times 40$ and $100 \times 100)$ resolution to evaluate a percentage of sex chromatin presence. Altogether 50000 buccal epithelial cells have been studied to ascertain the modal rate of incidences of sex chromatin.

All the statistical analysis were performed using SPSS v 16 software (SPSS for windows, USA). Independent sample $t$-test and one-way ANOVA test followed by Post-hoc test (Bonferroni: Adjustment for multiple comparisons) were used to access the mean differences among different reproductive stages of the females. Further, to evaluate the individual trait, crosstab analysis was used. The level of significance was fixed at 0.05 .

The present study was approved by the Institutional Bio-Ethics Committee for Human \& Animal Research Studies, University of Calcutta (CU/BIOETHICS/HUMAN/2304/2020 dated 25/09/2014). 


\section{RESULTS}

Table 2 and 2a and figure 1 represented the sex chromatin prevalence of different reproductive stages of the studied population. The mean prevalence of sex chromatin among pre-menarche, menarche, pregnant, lactation, and menopause were 14. 09, 46. $77,50.84,59.22,30.21$, respectively. One-way ANOVA test revealed a significant $(F=1935.63 ; \mathrm{p}<0$. $05)$ difference among all reproductive stages where the prevalence of sex chromatin was found to be significantly $(\mathrm{p}<0.05)$ highest among the lactating mothers (59. 22 \pm 4.06$)$ and the lowest among the

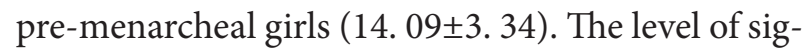
nificance remained the same even after adjustment of age. Post-hoc test (Bonferroni: Adjustment for multiple comparisons) also demonstrated that each mean difference between five reproductive stages was significant $(\mathrm{p}<0.05)$.

Furthermore, the prevalence of sex chromatin has been divided into 7 class intervals, and the distribution of studied population was demonstrated in table 3. Here it is seen that among the pre-menearcheal girls sex chromatin frequency was highest in the class intervals of $11-20.66 \%$ of menarcheal females have shown sex chromatin prevalence ranges from 41-50. Among the pregnant and lactating mother highest frequency was observed in class intervals of 51-60. Again, 53\% of menopausal females demonstrated 21-30 range of sex chromatin, whereas $47 \%$ shown $31-40$ range of sex chromatin. A significant association was observed between different reproductive stages and prevalence of sex chromatin. Contingency Coefficients between each reproductive stage have been computed and the result has shown highly significant value $(C C=0.836 ; \mathrm{p}<0.05)$.

\section{DISCUSSION}

In the present study, five reproductive stages according to their variable sex hormone circulation as pre-menarche, menarche, pregnant, lactation, and menopause have been taken into consideration. From the earlier studies, it is evident that there is a persistence of correlation in hormones with the growth and maturation of females, therefore, it would be apparent that female hormonal secretion varies in different reproductive stages (24-25). In continuation to that, the present study demonstrated significant variegation in the prevalence of sex chromatin among five reproductive stages (Table 2, $2 \mathrm{a}$ and 3; Figure 1), and the result might be indicative of a possible association between the changes in sex hormone levels during different reproductive stages and frequency of sex chromatin. Since the

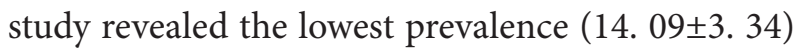
of sex chromatin in pre-menarcheal girls, may be due to very low levels of sex steroids (26). In comparison, the highest frequency of sex chromatin (59. $22 \pm 4.06)$ among the lactating females in this study may indicate high prolactin (27). However, the menarcheal females show moderate estrogen and progesterone levels (46.77 \pm 5.25$)$, and pregnant women (50. 84 \pm 4.23$)$, showing abundant estrogen-progesterone secretion (28). Lastly, menopausal females exhibited comparatively lower sex chromatin prevalence (30.21 \pm 3.30$)$ as most of the sex steroids except luteinizing hormone dramatically declined in their circulation (29). Earlier, plenty of studies from India and in global context had been conducted on variation in the prevalence of sex chromatin among normal females described the higher prevalence of sex chromatin (about 22\%) among 9-19 years females and lowest (about 10\%) in the aged females ( $\geq 50$ years) (14-18). In their study, Yen and Matsuyama compared the frequency of sex chromatin between older, middle, and young women and reported a significant decrease of the frequency with increasing age showed a good agreement with the present study (30).

Interestingly in our study, $100 \%$ visibility of sex chromatin has not been observed in any of the reproductive stages as the prevalence ranges from $<10$ to 70 (Table 3). However, according to the Lyon hypothesis, it is expected the existence of $100 \%$ sex chromatin in females (4). The conception forwarded by Moore and Barr and then Klinger implicitly stated that a fusion of the heterochromatic portions of the two chromosomes fabricates the sex chromatin of female somatic cells $(7,31)$. Along the way, Ohno et al. proposed that somatic association and positive heterozygosis of the X's are prerequisites for the appearance of sex chromatin in the interphase nucleus 
(32). Studies of the cell cycle by various authors have revealed that the diversified appearance of interphase nuclei with sex chromatin results from a quite different chromosome behaviour during telophase (33-34). Few researchers believed that the sex chromatin bodies represented true chromosomes that failed to alveolate during telophase and directly gave rise to the prophase chromosomes following a slight increase in size and minor shape modifications (3536). During telophase, chromosomes usually become indistinct in a process referred to as de-condensation and/or uncoiling (37). Therefore, owing to the variety of appearance and the relative lack of observable structural modifications of sex chromatin, it is conceptualized that the chromosomes during telophase disappear as they undergo some structural modifications and at interphase, they again become visible. A consensus eventually developed that most of the dense interphase chromatin correspond to the centromeric portions of chromosomes (38-39). Clarification for the structure of interphase nuclei assumes an unraveling of chromosomes into chromonemata that mingle in the nucleoplasm in the form of fibers (40). The structural integrity of interphase chromosomes depends on numerous attachments of chromosomal fibers to the nuclear envelope. During the G2 stage of interphase, the chromosomes progressively recondense and more compact than interphase, and the condensation process is catalyzed by several DNA properties, including cohesion and condensing (41). Conservation of the specific composition of chromosome organization in G, S, and G2 nuclei is observed to keep their three-dimensional integrity intact orchestrate the crucial structure throughout interphase (42).

Studies have shown a negative correlation between sex chromatin and mitosis rate (43-44). Schwarzacher reported that sex chromatin could be visible maximum of up to $90 \%$ in living human cells (45). The remaining $10 \%$ of sex chromatin could not be seen by any method. Furthermore, Mittwoch revealed that nuclei containing sex chromatin were on an average of about $6 \%$ smaller than the chromatin negative nuclei (46-47). The possibility has been given as the condensation of one $\mathrm{X}$ chromosome to form Barr body and the sex chromatin disappears at some stage during DNA synthesis when the nucleus might be expected to reach its maximum size. The latter would be in good agreement with the observation of an inverse relationship between the incidence of sex chromatin and mitosis rate (43-44). This is the plausible explanation behind the absence of $100 \%$ visibility of sex chromatin ranges from $<10$ to 70 among all participants (Table 3). Therefore, whenever the mitotic rate increases, the visibility of sex chromatin decreases proportionately. Consequently, the premenarcheal reproductive stage, which denotes a rapid mitotic cell cycle, demonstrated a lower prevalence of sex chromatin in the

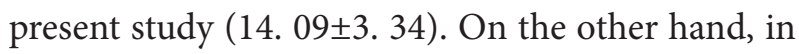
menstruating females who are fully grown adults, the rate of cell proliferation is comparatively lesser in normal circumstances and reflected in the relatively higher prevalence of sex chromatin in the

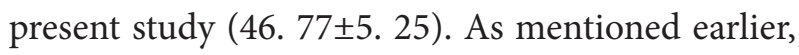
pregnancy and lactation are associated with lower mitotic rates and demonstrated the highest level of sex chromatin prevalence, such as $50.84 \pm 4.23$ and 59. 22 \pm 4.06 , respectively. However, the stage of menopause is associated with a decreased rate of mitosis, and the present study revealed a significantly $(\mathrm{p}<0.05)$ lower $(30.21 \pm 3.30)$ prevalence of sex chromatin (Table 3 ).

\section{CONCLUSION}

Therefore, based on the above discussion, the effect of sex steroids on cell transcription and differentiation may be manifested in the prevalence of sex chromatin. Thus, it is felt that the present study is the maiden attempt among Bengalee Hindu Caste females to understand the different reproductive stages of females in terms of the prevalence of sex chromatin. We also propose using sex chromatin prevalence as a biomarker or cytological marker to evaluate the hormonal influence in different reproductive stages of females. 
Mukherjee K, Das K. Sex Chromatin frequency in Buccal Mucosa cells among Bengalee Hindu females of West Bengal, India. Zdravstveni glasnik. 2021;7(1): 18-27.

Table 1. Details of the selected samples for the present study

\begin{tabular}{|c|c|c|l|}
\hline Group & Status & $\begin{array}{c}\text { Age range and Mean } \\
\pm \text { SD }\end{array}$ & Criteria for selection \\
\hline $\mathrm{A}(\mathrm{n}=100)$ & $\begin{array}{c}\text { Pre-menarche } \\
\text { (Non-ovulation) }\end{array}$ & $\begin{array}{c}(7-13 \text { years }) \\
9.58 \pm 1.27\end{array}$ & $\begin{array}{l}\text { Under the influence of minimal sex steroids and } \\
\text { menstruation has not been experienced for the last } \\
\text { one year }\end{array}$ \\
\hline $\mathrm{B}(\mathrm{n}=100)$ & $\begin{array}{c}\text { Menarche } \\
\text { (Ovulation) }\end{array}$ & $\begin{array}{c}(18-29 \text { years }) \\
22.34 \pm 2.81\end{array}$ & $\begin{array}{l}\text { Under the influence of sex steroids and experienced } \\
\text { menstruation for the last one year uninterruptedly, } \\
\text { non-users of oral contraceptives }\end{array}$ \\
\hline $\mathrm{C}(\mathrm{n}=100)$ & Pregnant & $(18-37$ years $)$ & $\begin{array}{l}\text { Under the influence of high-level natural sex steroids } \\
\text { and considered } 3 \text { trimesters }\end{array}$ \\
\hline $\mathrm{D}(\mathrm{n}=100)$ & Lactation & $\begin{array}{c}25.56 \pm 4.61 \\
(18-37 \text { years })\end{array}$ & $\begin{array}{l}\text { Under the influence of sex steroids and prolactin hor- } \\
\text { mone. Breast feeding for the last six months }\end{array}$ \\
\hline $\mathrm{E}(\mathrm{n}=100)$ & Menopausal & $(45-67$ years $)$ & $\begin{array}{l}\text { Under the physiological withdrawal of sex steroids } \\
\text { and not experiencing menstruation for the last one } \\
\text { year }\end{array}$ \\
\hline
\end{tabular}

Table 2. Sex-Chromatin Prevalence of the Different Reproductive Stages of Normal Females

\begin{tabular}{|c|c|c|c|c|c|c|c|c|}
\hline \multirow{2}{*}{ Reproductive Profile } & \multirow{2}{*}{ Mean } & \multirow{2}{*}{ SD } & \multirow{2}{*}{$\mathbf{F}$} & \multirow{2}{*}{$\mathbf{p}$} & \multicolumn{4}{|c|}{ After Adjusting Age } \\
\hline & & & & & Mean & SE & $\mathbf{F}$ & $\mathbf{p}$ \\
\hline Pre-menarche & 14.09 & 3.34 & \multirow{6}{*}{1935.63} & \multirow{6}{*}{$<0.001$} & 14.44 & 0.84 & \multirow{6}{*}{1918.55} & \multirow{6}{*}{$<0.001$} \\
\hline Menarche & 46.77 & 5.25 & & & 46.90 & 0.49 & & \\
\hline Pregnant & 50.84 & 4.23 & & & 50.89 & 0.42 & & \\
\hline Lactation & 59.22 & 4.06 & & & 59.23 & 0.41 & & \\
\hline Menopause & 30.21 & 3.30 & & & 29.67 & 1.20 & & \\
\hline Total & 40.23 & 16.65 & & & 40.23 & 0.67 & & \\
\hline
\end{tabular}

Table 2a. Post-hoc (Bonferroni) test Adjustment for multiple comparisons: After Adjusting Age (Pair wise Comparisons)

\begin{tabular}{|c|c|c|c|c|c|}
\hline $\begin{array}{c}\text { Reproductive } \\
\text { Profile }\end{array}$ & Pre-menarche & Menarche & Pregnant & Lactation & Menopause \\
\hline Pre-menarche & $\begin{array}{l}\text { Mean } \\
\text { Difference }\end{array}$ & -32.460 & -36.455 & -44.797 & -15.238 \\
\hline Menarche & $<0.001$ & $\begin{array}{l}\text { Mean } \\
\text { Difference }\end{array}$ & -3.995 & -12.336 & 17.223 \\
\hline Pregnant & $<0.001$ & $<0.001$ & \begin{tabular}{|l} 
Mean \\
Difference
\end{tabular} & -8.341 & 21.218 \\
\hline Lactation & $<0.001$ & $<0.001$ & $<0.001$ & $\begin{array}{l}\text { Mean } \\
\text { Difference }\end{array}$ & 29.559 \\
\hline Menopause & $<0.001$ & $<0.001$ & $<0.001$ & $<0.001$ & $\begin{array}{l}\text { Mean } \\
\text { Difference }\end{array}$ \\
\hline
\end{tabular}

$\mathrm{MD}=$ Mean differences (Upper Diagonal), $\mathrm{p}=$ Probability Value (Lower Diagonal) 
Mukherjee K, Das K. Sex Chromatin frequency in Buccal Mucosa cells among Bengalee Hindu females of West Bengal, India. Zdravstveni glasnik. 2021;7(1): 18-27.

Table 3. Distribution of Sex Chromatin Prevalence among Normal Females of Bengalee Hindu Caste

\begin{tabular}{|c|c|c|c|c|c|c|}
\hline \multirow{2}{*}{$\begin{array}{c}\text { Sex Chromatin } \\
\text { Prevalence }\end{array}$} & \multicolumn{5}{|c|}{ Reproductive Profile } & \multirow{2}{*}{ Total } \\
\hline & Pre-menarche & Menarche & Pregnant & Lactation & Menopause & \\
\hline \multirow{2}{*}{$\leq 10$} & 17 & 0 & 0 & 0 & 0 & 17 \\
\hline & $17.0 \%$ & $.0 \%$ & $.0 \%$ & $.0 \%$ & $.0 \%$ & $3.4 \%$ \\
\hline \multirow{2}{*}{$11-20$} & 81 & 0 & 0 & 0 & 0 & 81 \\
\hline & $81.0 \%$ & $.0 \%$ & $.0 \%$ & $.0 \%$ & $.0 \%$ & 16. $2 \%$ \\
\hline \multirow{2}{*}{$21-30$} & 2 & 0 & 0 & 0 & 53 & 55 \\
\hline & 2. $0 \%$ & $.0 \%$ & $.0 \%$ & $.0 \%$ & $53.0 \%$ & $11.0 \%$ \\
\hline \multirow{2}{*}{$31-40$} & 0 & 11 & 2 & 0 & 47 & 60 \\
\hline & $.0 \%$ & $11.0 \%$ & $2.0 \%$ & $.0 \%$ & $47.0 \%$ & $12.0 \%$ \\
\hline \multirow{2}{*}{$41-50$} & 0 & 66 & 40 & 1 & 0 & 107 \\
\hline & $.0 \%$ & $66.0 \%$ & $40.0 \%$ & 1. $0 \%$ & $.0 \%$ & $21.4 \%$ \\
\hline \multirow{2}{*}{$51-60$} & 0 & 23 & 58 & 67 & 0 & 148 \\
\hline & $.0 \%$ & $23.0 \%$ & $58.0 \%$ & $67.0 \%$ & $.0 \%$ & $29.6 \%$ \\
\hline \multirow{2}{*}{$61-70$} & 0 & 0 & 0 & 32 & 0 & 32 \\
\hline & $.0 \%$ & $.0 \%$ & $.0 \%$ & $32.0 \%$ & $.0 \%$ & $6.4 \%$ \\
\hline \multirow[t]{2}{*}{ Total } & 100 & 100 & 100 & 100 & 100 & 500 \\
\hline & $100.0 \%$ & $100.0 \%$ & $100.0 \%$ & $100.0 \%$ & $100.0 \%$ & $\begin{array}{l}100 . \\
0 \%\end{array}$ \\
\hline
\end{tabular}

Contingency Coefficient $(\mathrm{CC})=0.836 ; \mathbf{p}<0.001$

\begin{tabular}{|l|c|c|c|c|c|}
\hline Reproductive Profile & Pre-menarche & Menarche & Pregnant & Lactation & Menopause \\
\hline
\end{tabular}

\begin{tabular}{|l|c|c|c|c|c|}
\hline Pre-menarche & $\mathbf{C C}$ & 0.707 & 0.707 & 0.707 & 0.700 \\
\hline Menarche & $<0.001$ & $\mathbf{p C}$ & 0.349 & 0.624 & 0.672 \\
\hline Pregnant & $<0.001$ & $<0.001$ & $\mathbf{p C}$ & 0.514 & 0.700 \\
\hline Lactation & $<0.001$ & $<0.001$ & $<0.001$ & $\mathbf{C C}$ & 0.707 \\
\hline Menopause & $<0.001$ & $<0.001$ & $<0.001$ & $<0.001$ & $\mathbf{P C}$ \\
\hline
\end{tabular}

$\mathrm{CC}=$ Contingency Coefficient (Upper Diagonal), $\mathrm{p}=$ Probability Value (Lower Diagonal) 


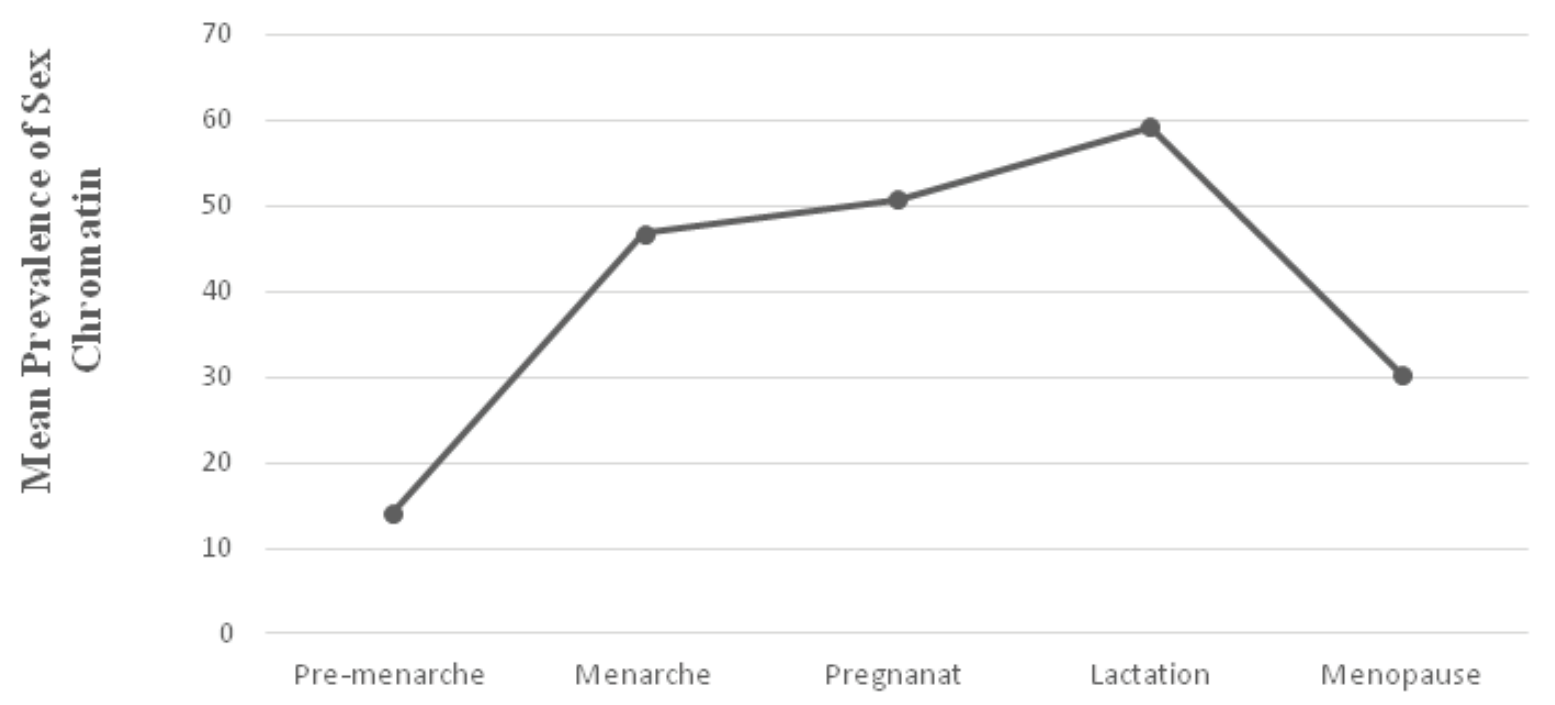

Reproductive Profile

Figure 1. Graphical Representation Sex-Chromatin Prevalence of the Different Physiological Phases of Normal Females

\section{REFERENCES}

1. Walker CL, Cargile CB, Floy KM, Delannoy $\mathrm{M}$, Migeon BR. The Barrbody is a looped X chromosome formed by telomere association. Proc Natl Acad Sci. 1991; 88: 6191-6195.

2. Heard E, Christine M, Disteche J. Dosage compensation in mammals: fine-tuning the expression of the X chromosome. Genes Dev. 2006; 20: 1848-1867.

3. Chow CJ, Heard E. Nuclear Organization and Dosage Compensation. Cold Spring Harb Perspect Biol. 2010; 2: 1-15.

4. Muller HJ. Further studies on the nature and causes of gene mutations. In: Jones DF, editor. Proceedings of 6th International Congress of Genetics. Menasha, WI: Banta; 1932. p. 213255.

5. Payer B, Lee JT, Namekawa SH. X-inactivation and $\mathrm{X}$-reactivation: epigenetic hallmarks of mammalian reproduction and pluripotent stem cells. Hum Genet. 2011; 130: 265-280.
6. Payer B, Lee JT. Coupling of X-chromosome reactivation with the pluripotent stem cell state. RNA Biol. 2014; 11: 798-807.

7. Moore KL, Graham MA, Barr ML. The detection of chromosomal sex in hermaphrodites from a skin biopsy. Surg Gynecol Obstet. 1953; 96: 641-648.

8. Grumbach MM, Van WykJJ, Wilkins L. Chromosomal sex in gonadal dysgenesis (ovarian agenesis). Relationship to male pseudohermaphrodism and theories of human sex differentiation. Journal Clin Endocrinol Metab. 1955; 15: 1161-1193.

9. Plunkett ER, Barr ML. Testicular dysgenesis affecting the seminiferous tubules principally, with chromatin positive nuclei. Lancet. 1956; 271: 853-856.

10. Nielsen J, Fischer M. Sex-Chromatin and Sex-Chromosome Abnormalities in Male Hypogonadal Mental Patients. Br J Psychiatry. 1965; 111: 641-647. 
11. Azoury RS, Jones HW. Cytogenetic findings in patients with congenital absence of vagina. Am J Obstet. 1966; 94: 178-180.

12. Lakshmy GV, Singh S, Sharma D. Cytogenetic studies in primary amenorrhoea. J Obstet and Gynaecol India. 1972; 23: 81-84.

13. de Mel T, Jayasekara R, Warnasooriya N. Screening for Turner Syndrome: how useful is the buccal smear test. Ceylon Med J. 1992; 37: 83-84.

14. Purandare $\mathrm{H}$, Chakravarty A. Buccal mucosal $\mathrm{X}$-chromatin frequency in the female. Indian J Med Res. 1980; 71: 790-794.

15. Bataineh ZM, Al-Azab MA. Prevalence of $\mathrm{X}$-chromatin in Jordanian women. Saudi Med J. 2004; 25: 456-458.

16. Verma U, Chowdhary DS, Chhabra S. Sex Chromatin Positive Cells in the Buccal Smears of Normal Newborn Females. IJBMR. 2013; 4: 3317-3319.

17. Mukherjee K. A Study on Prevalence of Sex Chromatin during Different Reproductive Stage of Bengalee Hindu Caste Females. Orient Anthropol. 2013; 13: 493-504.

18. Mukherjee K, Barman MK, Bandyopadhyay AR. Prevalence of Sex Chromatin in Bengalee Caste Hindu Females: Study on Interrelationship of Hormones. IJPSS. 2014; 4: 68-76.

19. Roede MJ. Sex chromatin scores in oral mucosa and hair root sheaths of human females. Acta Morphol Neerl Scand. 1977; 15: 269274.

20. Garza-chapa R, Alvarez-de SM, Marroquin MA, Gutierrez O. Effects of Hormonal factors on the frequency of sex chromatin. Ginecol Obstet de Méx. 1977; 42: 257-268.

21. DeSampaio LC, DeSampaio Neto LF, Boschini Filho J, Wajchenberg M, Galvão JA, Ferreiro $\mathrm{M}$, et al. Frequency of $\mathrm{X}$-chromatin in pregnant women during the second trimester of gestation. Rev Paul Med. 1992; 110: 19599.
22. Sharma A, Talukdar G. Laboratory procedures in human genetics. Kolkata: Calcutta Nucleus; 1974.

23. Weiner JS, Lourie JA. Practical Human Biology. London: Academic Press; 1981.

24. Müller L, Müller E, Kornexl E, Raschner C. The relationship between physical motor skills, gender and relative age effects in young Austrian alpine ski racers. Int J Sports Sci Coach. 2015; 10: 69-86.

25. Rogol AD. Human sex chromosome aneuploidies: The hypothalamic-pituitary-gonadal axis. Am J Med Genet C Semin Med Genet. 2020; 184: 313-319.

26. Ankarberg C, Norjavaara E. Diurnal rhythm of testosterone secretion before and throughout puberty in healthy girls: correlation with 17beta-estradiol and dehydroepiandrosterone sulfate. J Clin Endocrinol Metab. 1999; 84: 975-984.

27. Johnston JM, Amico JA. A prospective longitudinal study of the release of oxytocin and prolactin in response to infant suckling in long term lactation. J Clin Endocrinol Metab. 1986; 62: 653-657.

28. Kumar P, Magon N. Hormones in pregnancy. Niger Med J. 2012; 53: 179-183.

29. Dennerstein L, Lehert P, Burger H. The relative effects of hormones and relationship factors on sexual function of women through the natural menopausal transition. Fertil Steril. 2005; 84: 174-180.

30. Yen FF, Matsuyama SS, Jarvik LF. X chromatin and chromosome examination in aged women. Mech Ageing Dev. 1981; 16: 55-60.

31. Klinger HP, Schwarzacher HG. The Sex chromatin and heterochromatic bodies in human diploid and polyploid nuclei. J Biophys Biochem Cytol. 1960; 8: 345-364.

32. Ohno S, Kaplan WD, Kinosita R. Formation of the sex chromatin by a single $\mathrm{X}$ chromosome in liver cells of Rattus norvegicus. Exp Cell Res. 1959; 18: 415-418. 
33. Rosenberg O. Uber die Individualitat der Chromosomen im Pflanzenreich. Flora. 1904; 93: 251-259.

34. Comings DE. The duration of replication of the inactive $\mathrm{X}$ chromosome in humans based on the persistence of the heterochromatic sex chromatin body during DNA synthesis. Cytogenetics. 1967; 6: 20-37.

35. Jacob J, Stalin JL. Electron microscope studies on salivary gland cells. I. The nucleus of Bradysiamycorum Frey (Sciaridae), with special reference to the nucleolus. J Cell Biol. 1963; 17: 153-165.

36. Stevens BJ. The Fine Structure of The Nucleolus During Mitosis in The Grasshopper Neuroblast Cell. J Cell Biol; 1965; 24: 349-368.

37. Brown WV, Bertke EM. Textbook of Cytology 2. ed. St Louis: C. V. Mosby; 1974.

38. Cooper GM. The Cell: A Molecular Approach 2. ed. Washington, DC: Sunderland Mass; 2000.

39. Alberts B, Johnson A, Lewis J, Raff M, Roberts K, Walter P. Molecular Biology of the Cell 4. ed. New York: Garland Science; 2002.

40. Brasch K, Setterfield G. Structural organization of chromosomes in interphase nuclei. Exp Cell Res. 1974; 83: 175-185.
41. Hagstrom KA, Meyer BJ. Condensin and cohesin: more than chromosome compactor and glue. Nat Rev Genet. 2003; 4: 520-534.

42. Stack SM, Brown DB, Dewey WC. Visualization of Interphase Chromosomes. J Cell Sci. 1977; 26: 281-299.

43. Miles CP. Morphology and functional relations of sex chromatin in cultured amnion cells. Exp Cell Res. 1960; 20: 324-337.

44. Therkelsen AJ, Petersen GB. Frequency of sex-chromatin-positive cells in the logarithmic and postlogarithmic growth phases of human cells in tissue culture. Exp Cell Res. 1962; 28: 588-590.

45. Schwarzacher HG. Sex chromatin in living human cells in vitro. Cytogenetics. 1963; 2: 117-128.

46. Mittwoch U. Barr bodies and nuclear size in cultured human fibroblasts. Nature. 1963; 198: 975-997.

47. Mittwoch U. Frequency of drumsticks in normal women and in patients with chromosomal abnormalities. Nature. 1964; 201: 317-319. 


\title{
UČESTALOST SPOLNOG KROMATINA U STANICAMA BUKALNE SLUZNICE MEDU ŽENAMA HINDUISTIČKE VJERE ZAPADNOG BENGALA U INDIJI
}

\author{
Koel Mukherjee ${ }^{1}$, Kaustav Das ${ }^{2}$ \\ ${ }^{1}$ Institut za antropološka istraživanja, Andaman \& Nicobar Regionalni Centar, Port Blair, India \\ ${ }^{2}$ Odjel za antropologiju, Koledž Bangabasi, Kolkata, India
}

\section{SAŽETAK}

Uvod: Kvantitativno određivanje spolnog kromatina u staničnim jezgrama pokazalo je povezanost između prevalencije spolnog kromatina i razine hormona u ženskim reproduktivnim ciklusima.

Cilj: Cilj ovog istraživanja je razumjeti prevalenciju spolnog kromatina među različitim hormonskim reproduktivnim fazama hinduističkih žena u kastama koje žive u zapadnom Bengalu u Indiji.

Metode i ispitanici: Uzorci bukalnog razmaza prikupljeni su od 500 naizgled zdravih žena svrstanih u 5 različitih reproduktivnih faza predmenstrualna, menstrualna, trudnoća, dojenje i menopauza. Nasumično je proučeno 100 stanica od svakog pojedinca i 100 sudionika iz svake skupine.

Rezultati: Rezultat je otkrio diferencijalnu prevalenciju spolnog kromatina među sudionicama u različitim reproduktivnim fazama (rasponi <10-> 60). Prosječna prevalencija spolnog kromatina bila je najveća među majkama u laktaciji $(59,22$ $\pm 4,06)$, a najmanja među ženama u predmenstrualnoj fazi $(14,09 \pm 3,34)$. Utvrđena je značajna prosječna razlika među ženama u svim reproduktivnim fazama $(\mathrm{p}<0,05)$.

Zaključak: Ovi su rezultati ukazuju na moguću povezanost između prisutnosti steroidnih hormona i prevalencije spolnog kromatina. Ovo je istraživanje također predlaže učestalost spolnog kromatina kao biomarkera, ali kao i citološki markera određenih reproduktivnih faza žena pod utjecajem hormona.

Key words: spolni kromatin; hinduističke žene u kastama; Bengal; steroidni hormoni; reproduktivne faze

Osoba za razmjenu informacija:

Dr. sc. Koel Mukherjee, antropolog

Odjel za fizičku antropologiju, Institut za antropološka istraživanja Andaman \& Nicobar Regionalni Centar Port Blair 744101

E-mail: koelanthro@gmail.com 